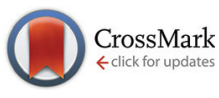

Cite this: Food Funct., 2015, 6, 1900

\section{A comparative study on edible Agaricus mushrooms as functional foods}

\author{
Jasmina Glamočlija, ${ }^{a}$ Dejan Stojković, ${ }^{a}$ Miloš Nikolić, ${ }^{a}$ Ana Ćirić, ${ }^{a}$ Filipa S. Reis, ${ }^{b}$ \\ Lillian Barros, ${ }^{b}$ Isabel C. F. R. Ferreira*b and Marina Soković*a
}

Received 10th December 2014, Accepted 18th April 2015

DOI: 10.1039/c4fo01135j www.rsc.org/foodfunction

\begin{abstract}
Agaricus bisporus is a cultivated mushroom; A. bitorquis, A. campestris and A. macrosporus are edible mushrooms growing wild in nature. A chemical characterization was carried out with samples that originated in Serbia. Antioxidant, antimicrobial and anti-quorum sensing properties of their methanolic and ethanolic extracts were assessed. A. campestris had the lowest caloric value and total sugar content and showed the highest concentration in organic and phenolic acids, as also in tocopherols (mainly $\gamma$-tocopherol). In general, the methanolic extracts showed higher antioxidant, but lower antibacterial and antifungal potential than ethanolic ones. Sub-inhibitory concentrations of the ethanolic extracts demonstrated reduction of virulence factors, $A Q$ inhibition zones, twitching and swimming motility. The biofilm forming capability of $P$. aeruginosa PAO1 was also reduced in a concentration-dependent manner at sub-MIC values. The extracts of the tested Agaricus species are a promising source of antioxidant, antimicrobial and antiquorum sensing compounds.
\end{abstract}

\section{Introduction}

The consumption of wild-growing mushrooms has been preferred to cultivated species in many countries of Europe. About 200 edible species have been identified in various parts of the world. ${ }^{1}$ Important edible mushrooms belong to the Agaricus genus. A. bisporus is one of the most economically important edible species and, besides its nutritional value, it is also recognized for medicinal properties including antitumor, anti-aromatase, antimicrobial, immunomodulatory, antiinflammatory as well as antioxidant. ${ }^{2-6}$ A. bitorquis is an edible white mushroom, similar to the common button mushroom that is sold commercially. It is also commonly known as torq, banded agaric, spring agaric, or pavement mushroom, as it has been recorded pushing up paving slabs. ${ }^{7}$ The meadow mushroom, A. campestris, is a white mushroom that is closely related to A. bisporus. In most areas it is a fall mushroom and, as its common and Latin names suggest, it comes up in meadows, fields, and grassy areas, after rains, and has a pleasant taste. A. macrosporus is known as Horse mushroom and is a stately and impressive species, recognized by its preference for grassy areas and sweetish smell. ${ }^{7}$

\footnotetext{
${ }^{a}$ Institute for Biological Research "Siniša Stanković, University of Belgrade, Bulevar Despota Stefana 142, 11000 Belgrade, Serbia.E-mail: mris@ibiss.bg:ac.rs; Fax: +381-11-2761433; Tel: +381-11-2078419

${ }^{b}$ Mountain Research Centre (CIMO), ESA, Polytechnic Institute of Bragança, Campus de Santa Apolónia, Ap. 1172, 5301-855 Bragança, Portugal. E-mail: iferreira@ipb.pt; Fax: +351-273-325405; Tel: +351-273-303219
}

All these species are easy to recognize and they can be collected in large quantities. The taste and size of their fruiting bodies are important factors for considering these mushrooms as potential important foodstuffs. Although the wild edible mushrooms are commercialized at higher prices than the cultivated species, the majority of the consumers prefer wild mushrooms due to their characteristic flavor and texture. There are many reports on the nutritional value of cultivated and wild edible mushrooms from different countries, but no information is available regarding these three wild species from Serbia.

Antioxidants play an important role in defending the body against free radical attack by delaying or inhibiting the oxidation of lipids, DNA or proteins, preventing or repairing the damage to cells. ${ }^{3,8}$ Furthermore, although the use of antimicrobial agents has been decreasing, the spread and severity of a wide variety of infectious diseases, as also the resistance developed by bacteria and fungi demands new alternatives. ${ }^{9}$ Otherwise, many food products are perishable and also require protection from microbial spoilage during preparation, storage and distribution, in order to guarantee the acceptable shelf-life and organoleptic characteristics.

With these concepts in mind, the main focus of this study was to perform the chemical characterization of four Agaricus spp. from Serbia, regarding their nutritional value, hydrophilic and lipophilic compounds, and also to evaluate their biological activity (antioxidant, antimicrobial and antiquorum properties). 


\section{Materials and methods}

\subsection{Mushroom species}

Cultivated A. bisporus was bought at a local market (Belgrade, Serbia), and wild growing A. bitorquis, A. campestris and A. macrosporus (Avala mountain, Krupanj, Divcibare mountain, respectively) were collected in Serbia, in autumn 2013, and authenticated by Dr Jasmina Glamočlija (Institute for Biological Research, University of Belgrade, Serbia). A voucher specimen has been deposited at the Fungal Collection Unit of the Mycological Laboratory, Department for Plant Physiology, Institute for Biological Research "Siniša Stanković", Belgrade, Serbia, under numbers Abis 12-2013, Abit 45-2013, Acam 23-2013, Amac 33-2013. All the samples were lyophilised (FreeZone 4.5 model 7750031, Labconco, Kansas, USA), reduced to a fine dried powder (20 mesh), mixed to obtain homogeneous samples and stored in a desiccator, protected from light, until further analysis.

\subsection{Standards and reagents}

Acetonitrile 99.9\%, $n$-hexane $95 \%$ and ethyl acetate $99.8 \%$ were of HPLC grade from Fisher Scientific (Lisbon, Portugal). The fatty acid methyl ester (FAME) reference standard mixture 37 (standard 47885-U) was purchased from Sigma (St. Louis, MO, USA), and so were other individual fatty acid isomers and standards of tocopherols, ergosterol, sugars, organic acids and phenolic compounds, and trolox (6-hydroxy-2,5,7,8-tetramethylchroman-2-carboxylic acid). Racemic tocol, $50 \mathrm{mg}$ $\mathrm{mL}^{-1}$, was purchased from Matreya (PA, USA). 2,2-Diphenyl1-picrylhydrazyl (DPPH) was obtained from Alfa Aesar (Ward Hill, MA, USA). Mueller-Hinton agar (MH) and malt agar (MA) were obtained from the Institute of Immunology and Virology, Torlak (Belgrade, Serbia). Dimethylsulfoxide (DMSO) (Merck KGaA, Germany) was used as a solvent. Phosphate buffered saline (PBS) was obtained from Sigma Chemical Co. (St. Louis, MO, USA). Methanol and all other chemicals and solvents were of analytical grade and purchased from common sources. Water was treated in a Milli-Q water purification system (TGI Pure Water Systems, Greenville, SC, USA).

\subsection{Chemical characterization of Agaricus spp.}

(a) Nutritional value. The samples were analysed for their chemical composition (moisture, proteins, fat, carbohydrates and ash) through AOAC procedures. ${ }^{10}$ The crude protein content $(\mathrm{N} \times 4.38)$ of the samples was estimated by the macroKjeldahl method; the crude fat was determined by extracting a known weight of powdered sample with petroleum ether, using Soxhlet apparatus; the ash content was determined by incineration at $600 \pm 15{ }^{\circ} \mathrm{C}$. Total carbohydrates were calculated by difference. The energy contribution is calculated according to the following equation: energy $(\mathrm{kcal})=4 \times$ $(\mathrm{g}$ protein $+\mathrm{g}$ carbohydrate $)+9 \times(\mathrm{g}$ fat $)$.

(b) Hydrophilic compounds. Sugars. Following the extraction procedure described by Reis et $a .^{11}$ free sugars were determined by a High Performance Liquid Chromatography (HPLC) system consisting of an integrated system with a pump
(Knauer, Smartline System 1000, Berlin, Germany), a degasser system (Smartline Manager 5000) and an auto-sampler (AS-2057 Jasco, Easton, MD, USA), coupled to a refraction index detector (RI detector Knauer Smartline 2300). Sugar identification was made by comparing the relative retention times of sample peaks with standards. Data were analyzed using Clarity 2.4 Software (DataApex, Prague, Czech Republic). Quantification was based on the RI signal response of each standard, using the internal standard (IS, raffinose) method and by using calibration curves obtained from the commercial standards of each compound. The results are expressed in $g$ per $100 \mathrm{~g}$ of dry weight.

Organic acids. Following the extraction procedure described by Barros et $a l .{ }^{12}$ organic acids were determined by ultra fast liquid chromatography (UFLC, Shimadzu 20A Series, Kyoto, Japan) coupled with a photodiode array detector (PDA). The organic acids were quantified by the comparison of the area of their peaks recorded at $215 \mathrm{~nm}$ with calibration curves obtained from commercial standards of each compound. The results were expressed in g per $100 \mathrm{~g}$ of dry weight.

Phenolic compounds. Following the extraction procedure described by Barros et al. ${ }^{13}$ phenolic acids and related compounds were determined using the UFLC mentioned above. Detection was carried out in a photodiode array detector (PDA), using $280 \mathrm{~nm}$ as the preferred wavelength. The phenolic acids and related compounds were quantified by a comparison of the area of their peaks recorded at $280 \mathrm{~nm}$ with calibration curves obtained from commercial standards of each compound. The results are expressed in $\mathrm{mg}$ per $100 \mathrm{~g}$ of dry weight.

(c) Lipophilic compounds. Fatty acids. Following the extraction transesterification procedures described by Reis et $a{ }^{11}$ fatty acids were determined using a gas chromatographer (DANI 1000, Contone, Switzerland) equipped with a split/splitless injector and a flame ionization detector (GC-FID). Fatty acid identification was made by comparing the relative retention times of FAME peaks from samples with standards. The results were recorded and processed using CSW 1.7 software (DataApex 1.7, Prague, Czech Republic) and expressed in relative percentage of each fatty acid.

Tocopherols. Following the extraction procedure described by Heleno et $a .^{14}$ tocopherols were determined by HPLC (equipment described above, for sugar composition), and a fluorescence detector (FP-2020; Jasco, Easton, MD, USA) programmed for excitation at $290 \mathrm{~nm}$ and emission at $330 \mathrm{~nm}$. The compounds were identified by chromatographic comparison with authentic standards. Quantification was based on the fluorescence signal response of each standard, using the IS (tocol) method and by using calibration curves obtained from commercial standards of each compound. The results are expressed in $\mu \mathrm{g}$ per $100 \mathrm{~g}$ of dry weight.

\subsection{Extract preparation}

The lyophilized powder ( $1 \mathrm{~g}$ ) was extracted by stirring with $40 \mathrm{~mL}$ of methanol $\left(25^{\circ} \mathrm{C}\right.$, at $\left.150 \mathrm{rpm}\right)$ for $1 \mathrm{~h}$ and subsequently filtered through Whatman No. The residue was then 
extracted with $20 \mathrm{~mL}$ of methanol for $1 \mathrm{~h}$. The combined methanolic extracts were evaporated at $40^{\circ} \mathrm{C}$ (rotary evaporator Büchi R-210) to dryness. The ethanolic extracts were prepared following the procedure described by Cheng et al. ${ }^{2}$ with some modifications. The dry fruiting bodies $(1 \mathrm{~g})$ were extracted by stirring with $30 \mathrm{~mL}$ of $90 \%$ ethanol during $48 \mathrm{~h}$ at $70{ }^{\circ} \mathrm{C}$. The extracts were filtered and centrifuged to get a clear liquid, and evaporated at $40{ }^{\circ} \mathrm{C}$. The extracts were re-dissolved in (a) the corresponding extraction solvent for the antioxidant activity assays $\left(20 \mathrm{mg} \mathrm{mL} \mathrm{mL}^{-1}\right.$ ), (b) $5 \%$ solution of DMSO in distilled water for the antimicrobial activity assays $\left(100 \mathrm{mg} \mathrm{mL}^{-1}\right)$.

\subsection{Evaluation of the antioxidant potential of the Agaricus spp. extracts}

(a) General. Successive dilutions were made from the stock solution and subjected to different in vitro assays to evaluate the antioxidant activity of the samples. ${ }^{15}$ The sample concentrations providing $50 \%$ of antioxidant activity or 0.5 of absorbance $\left(\mathrm{EC}_{50}\right)$ were calculated from the graphs of antioxidant activity percentages (DPPH, $\beta$-carotene/linoleate and TBARS assays) or from absorbance at $690 \mathrm{~nm}$ (ferricyanide/ Prussian blue assay) against sample concentrations. Trolox was used as the standard.

(b) Folin-Ciocalteu assay. The extract solution $(1 \mathrm{~mL})$ was mixed with Folin-Ciocalteu reagent $(5 \mathrm{~mL}$, previously diluted with water $1: 10, \mathrm{v} / \mathrm{v}$ ) and sodium carbonate $\left(75 \mathrm{~g} \mathrm{~L}^{-1}, 4 \mathrm{~mL}\right)$. The tubes were vortex mixed for $15 \mathrm{~s}$ and allowed to stand for $30 \mathrm{~min}$ at $40^{\circ} \mathrm{C}$ for colour development. Absorbance was then measured at $765 \mathrm{~nm}$ (Analytik Jena Spectrophotometer; Jena, Germany). Gallic acid was used to obtain the standard curve and the reduction of Folin-Ciocalteu reagent by the samples was expressed as mg of gallic acid equivalents (GAE) per $\mathrm{g}$ of extract.

(c) Reducing power or ferricyanide/Prussian blue assay. The extract solutions with different concentrations $(0.5 \mathrm{~mL})$ were mixed with sodium phosphate buffer $\left(200 \mathrm{mmol} \mathrm{L}^{-1}\right.$, $\mathrm{pH} 6.6,0.5 \mathrm{~mL})$ and potassium ferricyanide $(1 \% \mathrm{w} / \mathrm{v}, 0.5 \mathrm{~mL})$. The mixture was incubated at $50{ }^{\circ} \mathrm{C}$ for $20 \mathrm{~min}$, and trichloroacetic acid $(10 \% \mathrm{w} / \mathrm{v}, 0.5 \mathrm{~mL})$ was added. The mixture $(0.8 \mathrm{~mL})$ was poured in the 48 well plates, the same with deionised water $(0.8 \mathrm{~mL})$ and ferric chloride $(0.1 \% \mathrm{w} / \mathrm{v}, 0.16 \mathrm{~mL})$, and the absorbance was measured at $690 \mathrm{~nm}$ using a ELX800 Microplate Reader (Bio-Tek Instruments, Inc; Winooski, VT, USA).

(d) DPPH radical-scavenging activity assay. This methodology was performed using the Microplate Reader mentioned above. The reaction mixture was prepared in a 96 well plates and consisted of $30 \mu \mathrm{L}$ of a concentration range of the extract and $270 \mu \mathrm{L}$ methanol containing DPPH radicals $\left(6 \times 10^{-5} \mathrm{~mol}\right.$ $\left.\mathrm{L}^{-1}\right)$. The mixture was left to stand for $30 \mathrm{~min}$ in the dark, and the absorption was measured at $515 \mathrm{~nm}$. The radical scavenging activity (RSA) was calculated as a percentage of DPPH discolouration using the equation: \% RSA $=\left[\left(A_{\mathrm{DPPH}}-A_{\mathrm{S}}\right) / A_{\mathrm{DPPH}}\right] \times$ 100 , where $A_{\mathrm{S}}$ is the absorbance of the solution containing the sample and $A_{\mathrm{DPPH}}$ is the absorbance of the DPPH solution.

(e) Inhibition of the $\beta$-carotene bleaching or $\beta$-carotene/ linoleate assay. A solution of $\beta$-carotene was prepared by dissolving $\beta$-carotene $(2 \mathrm{mg})$ in chloroform $(10 \mathrm{~mL})$. Two milli- litres of this solution were pipetted into a round-bottom flask. The chloroform was removed at $40{ }^{\circ} \mathrm{C}$ under vacuum and linoleic acid (40 mg), Tween 80 emulsifier (400 mg), and distilled water $(100 \mathrm{~mL})$ were added to the flask with vigorous shaking. Aliquots $(4.8 \mathrm{~mL})$ of this emulsion were transferred into test tubes containing $0.2 \mathrm{~mL}$ of a concentration range of the extract. The tubes were shaken and incubated at $50{ }^{\circ} \mathrm{C}$ in a water bath. As soon as the emulsion was added to each tube, the zero time absorbance was measured at $470 \mathrm{~nm}$. $\beta$-Carotene bleaching inhibition was calculated using the following equation: absorbance after $2 \mathrm{~h}$ of assay/initial absorbance) $\times 100$.

(f) Thiobarbituric acid reactive substances (TBARS) assay. Porcine (Sus scrofa) brains were obtained from official slaughtering animals, dissected, and homogenized with a Polytron in ice cold Tris- $\mathrm{HCl}$ buffer ( $20 \mathrm{mM}, \mathrm{pH} 7.4$ ) to produce a $1: 2 \mathrm{w} / \mathrm{v}$ brain tissue homogenate which was centrifuged at $3000 \mathrm{~g}$ for $10 \mathrm{~min}$. An aliquot $(100 \mu \mathrm{L})$ of the supernatant was incubated with $200 \mu \mathrm{L}$ samples of a concentration range of the extract in the presence of $\mathrm{FeSO}_{4}(10 \mathrm{mM} ; 100 \mu \mathrm{L})$ and ascorbic acid $(0.1 \mathrm{mM} ; 100 \mu \mathrm{L})$ at $37^{\circ} \mathrm{C}$ for $1 \mathrm{~h}$. The reaction was stopped by the addition of trichloroacetic acid $(28 \% \mathrm{w} / \mathrm{v}, 500 \mu \mathrm{L})$, followed by thiobarbituric acid (TBA, $2 \%, \mathrm{w} / \mathrm{v}, 380 \mu \mathrm{L}$ ), and the mixture was then heated at $80{ }^{\circ} \mathrm{C}$ for $20 \mathrm{~min}$. After centrifugation at $3000 \mathrm{~g}$ for $10 \mathrm{~min}$ to remove the precipitated protein, the color intensity of the malondialdehyde (MDA)-TBA complex in the supernatant was measured by its absorbance at $532 \mathrm{~nm}$. The inhibition ratio (\%) was calculated using the following formula: Inhibition ratio $(\%)=[(A-B) / A] \times 100 \%$, where $A$ and $B$ are the absorbance of the control and the sample solution, respectively.

\subsection{Evaluation of the antimicrobial activity of the Agaricus spp. extracts}

(a) Antibacterial activity. The Gram-positive bacteria Staphylococcus aureus (ATCC 6538), Bacillus cereus (clinical isolate), Micrococcus flavus (ATCC 10240) and Listeria monocytogenes (NCTC 7973), and the Gram-negative bacteria Pseudomonas aeruginosa (ATCC 27853), Salmonella typhimurium (ATCC 13311), Escherichia coli (ATCC 35210), and Enterobacter cloacae (human isolate), were used. The antibacterial assay was carried out by a microdilution method. ${ }^{16,17}$ The bacterial suspensions were adjusted with sterile saline to a concentration of $1.0 \times 10^{5}$ CFU $\mathrm{mL}^{-1}$. Mushroom extracts were dissolved in 5\% DMSO solution containing $0.1 \%$ Tween $80(\mathrm{v} / \mathrm{v})\left(10 \mathrm{mg} \mathrm{mL} \mathrm{mL}^{-1}\right)$ and added in Tryptic Soy broth (TSB) medium $(100 \mu \mathrm{L})$ with bacterial inoculum $\left(1.0 \times 10^{4} \mathrm{CFU}\right.$ per well). The lowest concentrations without visible growth (at the binocular microscope) were defined as concentrations that completely inhibited bacterial growth (MICs). The MICs obtained from the susceptibility testing of various bacteria to tested extracts were also determined by a colorimetric microbial viability assay based on reduction of an INT ( $p$-iodonitrotetrazolium violet) [2-(4iodophenyl)-3-(4-nitrophenyl)-5-phenyltetrazolium chloride; Sigma]) color and compared with positive control for each bacterial strain. The MBCs were determined by serial sub-cultivation of $2 \mu \mathrm{L}$ of tested compounds into microtitre plates con- 
taining $100 \mu \mathrm{L}$ of broth per well and further incubated for $24 \mathrm{~h}$. The lowest concentration with no visible growth was defined as the MBC, indicating 99.5\% killing of the original inoculum. The optical density of each well was measured at a wavelength of $655 \mathrm{~nm}$ by using Microplate manager 4.0 (BioRad Laboratories) and compared with a blank (broth medium plus diluted extracts) and the positive control. Streptomycin (Sigma P 7794) and ampicillin (Panfarma, Belgrade, Serbia) were used as positive controls $\left(1 \mathrm{mg} \mathrm{mL}^{-1}\right.$ in sterile physiological saline). Five percent DMSO was used as a negative control.

(b) Antifungal activity. Aspergillus fumigatus (human isolate), Aspergillus versicolor (ATCC 11730), Aspergillus ochraceus (ATCC 12066), Aspergillus niger (ATCC 6275), Trichoderma viride (IAM 5061), Penicillium funiculosum (ATCC 36839), Penicillium ochrochloron (ATCC 9112) and Penicillium verrucosum var. cyclopium (food isolate) were used. In order to investigate the antifungal activity of mushroom extract, a modified microdilution technique was used. ${ }^{18}$ The fungal spores were washed from the surface of agar plates with sterile $0.85 \%$ saline containing $0.1 \%$ Tween $80(\mathrm{v} / \mathrm{v})$ and spore suspension was adjusted with sterile saline to a concentration of $1.0 \times 10^{5}$. Extracts were dissolved in 5\% DMSO solution containing 0.1\% Tween $80(\mathrm{v} / \mathrm{v})\left(10 \mathrm{mg} \mathrm{mL}{ }^{-1}\right)$ and added in a broth malt medium with an inoculum $\left(0.005-3 \mathrm{mg} \mathrm{mL}^{-1}\right.$ for extracts). The lowest concentrations without visible growth (at the binocular microscope) were defined as MICs. The fungicidal concentrations (MFCs) were determined by serial subcultivation of $2 \mu \mathrm{L}$ of tested compounds dissolved in medium and incubated for $72 \mathrm{~h}$ at $28{ }^{\circ} \mathrm{C}$. The lowest concentration with no visible growth was defined as MFC indicating 99.5\% killing of the original inoculum. DMSO was used as a negative control, and commercial fungicides, bifonazole (Srbolek, Belgrade, Serbia) and ketoconazole (Zorkapharma, Šabac, Serbia), were used as positive controls $\left(1-3000 \mu \mathrm{g} \mathrm{mL}^{-1}\right)$. Five percent DMSO was used as a negative control.

\subsection{Antiquorum sensing (AQ) activity of mushroom extracts}

(a) Bacterial strains, growth media and culture conditions. P. aeruginosa PA01 (ATCC 27853) used in this study was from the collection of the Mycoteca, Institute for Biological Research "Sinisa Stankovic", Belgrade, Serbia. Bacteria were routinely grown in Luria-Bertani (LB) medium (1\% w/v NaCl, $1 \% \mathrm{w} / \mathrm{v}$ Tryptone, $0.5 \% \mathrm{w} / \mathrm{v}$ yeast extract) with shaking (220 rpm) and cultured at $37^{\circ} \mathrm{C}$.

(b) Biofilm formation. The effect of different concentrations of extracts (ranging from $0.5,0.25$ and 0.125 of MIC) on biofilm forming ability was tested on polystyrene flat-bottomed microtitre 96 well plates as described by Drenkard \& Ausubel ${ }^{19}$ with some modifications. Briefly, $100 \mu \mathrm{L}$ of an overnight culture of $P$. aeruginosa (inoculum size was $1 \times 10^{8} \mathrm{CFU}$ $\mathrm{mL}^{-1}$ ) was added to each well of the plates in the presence of $100 \mu \mathrm{L}$ subinhibitory concentrations (subMIC) of extracts $(0.5$, 0.25 and $0.125 \mathrm{MIC}$ ) or $100 \mathrm{~mL}$ medium (control). After incubation for $24 \mathrm{~h}$ at $37^{\circ} \mathrm{C}$, each well was washed twice with sterile PBS ( $\mathrm{pH} 7.4$ ), dried, and stained for $10 \mathrm{~min}$ with $0.1 \%$ crystal violet in order to determine the biofilm mass. After drying, $200 \mu \mathrm{L}$ of $95 \%$ ethanol (v/v) was added to solubilize the dye that had stained the biofilm cells. The excess stain was washed off with $\mathrm{dH}_{2} \mathrm{O}$. After $10 \mathrm{~min}$, the content of the wells was homogenized and the absorbance at $\lambda=625 \mathrm{~nm}$ was read on a Sunrise ${ }^{\mathrm{TM}}$ Tecan ELISA reader. The experiment was done in triplicate and repeated two times and values were presented as mean values $\pm \mathrm{SE}$.

(c) Discs-diffusion method for determination of AQ activity of mushroom extracts against $\boldsymbol{P}$. aeruginosa. $P$. aeruginosa was cultured overnight at $37{ }^{\circ} \mathrm{C}$ in $\mathrm{LB}$ medium and then adjusted to a concentration of $1.0 \times 10^{8} \mathrm{CFU} \mathrm{mL} \mathrm{m}^{-1}$ for final inoculum. Filter paper discs (Whatman; $4 \mathrm{~mm}$ in diameter) were impregnated with a solution of Agaricus spp. extracts (2.50, 1.25, 0.60, $0.30,0.15 \mathrm{mg}$ per disc), streptomycin and ampicillin (2.50, $1.25,0.60,0.30,0.15 \mathrm{mg}$ per disc). Discs were dried at room temperature ( $3 \mathrm{~h}$, protected from light), and aseptically placed onto the plates prior inoculated with $P$. aeruginosa $\left(1 \times 10^{8}\right.$ CFU $\mathrm{mL}^{-1}$ ). Petri dishes then were placed for incubation in a thermostat at $37{ }^{\circ} \mathrm{C}$ for $24 \mathrm{~h}$. After incubation, it was recorded whether inhibition or antiquorum zones were obtained. Minimal inhibitory concentrations were determined as the diameter of the growth clear inhibition zones around the discs (no growth), while antiquorum zones were determined as the transparent zones around the discs behind the margin of the inhibition zone. ${ }^{20}$

(d) Twitching and flagella motility. After growth in the presence or absence of Agaricus spp. extracts (subMIC), streptomycin and ampicillin (subMIC), the cells of $P$. aeruginosa PA01 were washed twice with sterile PBS and resuspended in PBS at $1 \times 10^{8} \mathrm{cfu} \mathrm{mL}^{-1}$ (OD of 0.1 at $660 \mathrm{~nm}$ ). Briefly, cells were stabbed into a nutrient agar plate with a sterile toothpick and incubated overnight at $37^{\circ} \mathrm{C}$. Plates were then removed from the incubator and incubated at room temperature for two more days. Colony edges and the zone of motility were measured with a light microscope. ${ }^{21}$ Fifty microlitres of extracts was mixed into $10 \mathrm{~mL}$ of molten $\mathrm{MH}$ medium and poured immediately over the surface of a solidified LBA plate as an overlay. The plate was point inoculated with an overnight culture of PAO1 once the overlaid agar had solidified and incubated at $37^{\circ} \mathrm{C}$ for 3 days. The extent of swimming was determined by measuring the area of the colony. ${ }^{22}$ The experiment was done in triplicate and repeated two times.

\subsection{Statistical analysis}

For each species, three samples were used and all the assays were carried out in triplicate. The results are expressed as mean values and standard errors, and analyzed using one-way analysis of variance (ANOVA) followed by Tukey's HSD test with $\alpha=0.05$. This analysis was carried out using the SPSS v. 22.0 program.

\section{Results and discussion}

\subsection{Chemical characterization of Agaricus spp.}

The results of the chemical characterization of four Agaricus species from Serbia are shown in Tables 1-3. Carbohydrates 
Table 1 Nutritional value and hydrophilic compounds in the studied Agaricus spp. (mean \pm SD) ${ }^{a}$

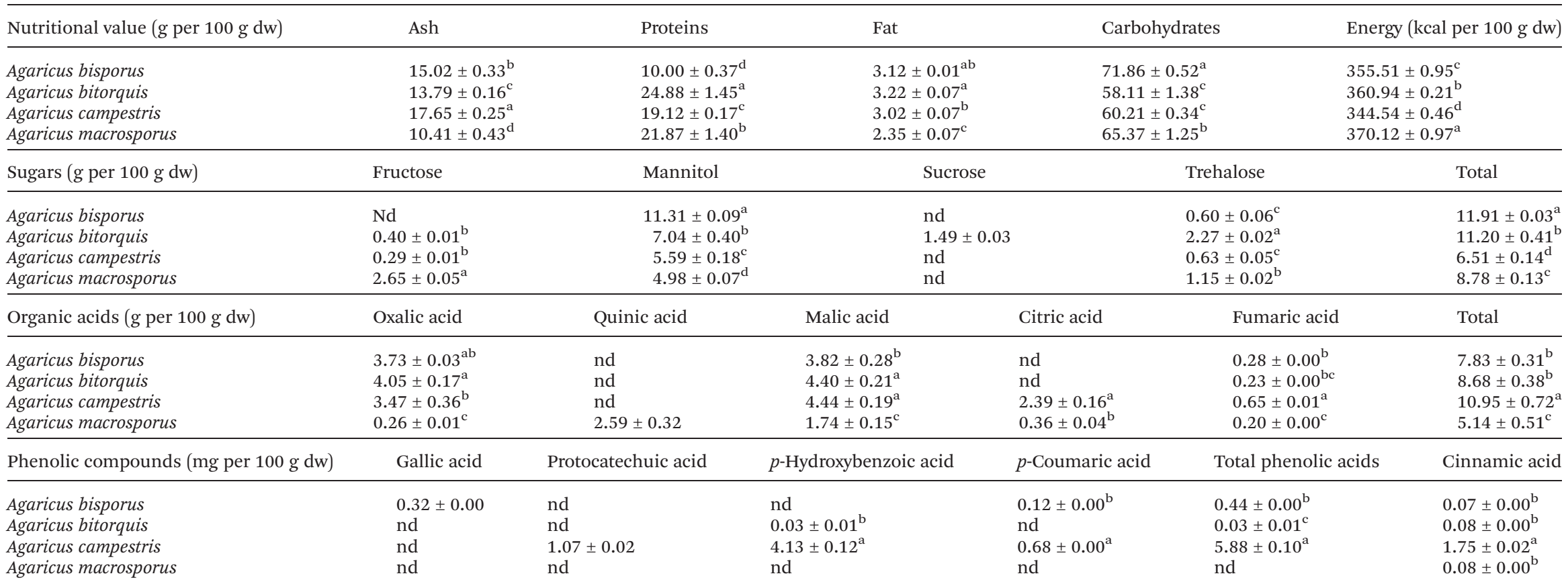

${ }^{a}$ nd, not detected; dw, dry weight. In each column different letters mean significant differences between species $(p<0.05)$. 
Table 2 Lipophilic compounds in the studied Agaricus spp. (mean \pm SD) ${ }^{a}$

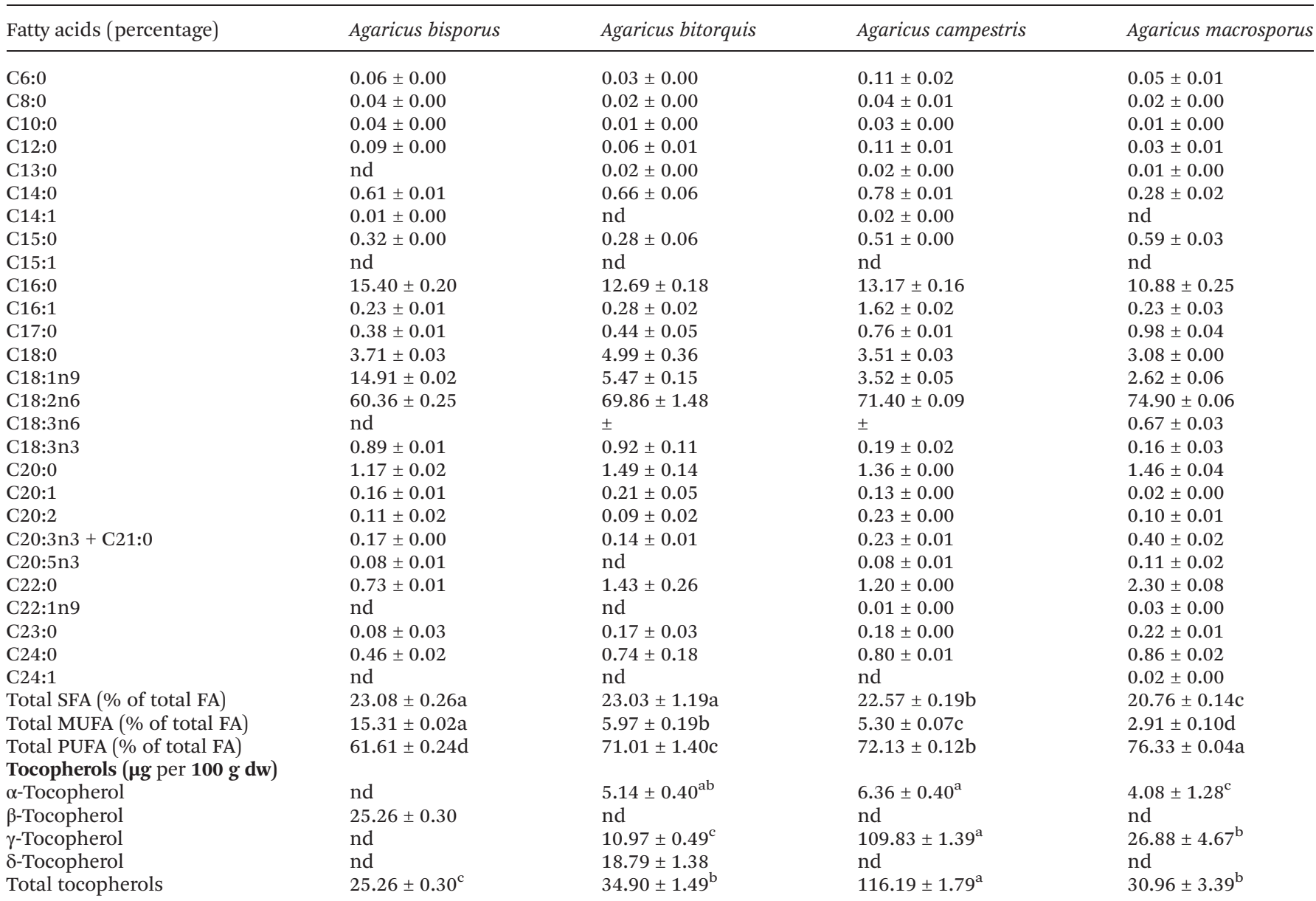

${ }^{a}$ nd, not detected; dw, dry weight. In each line different letters mean significant differences between species $(p<0.05)$.

Table 3 Antioxidant properties of the methanolic $(\mathrm{MeOH})$ and ethanolic (EtOH) extracts of the studied Agaricus spp. (mean \pm SD) ${ }^{a}$

\begin{tabular}{|c|c|c|c|c|c|}
\hline & $\begin{array}{l}\text { Folin-Ciocalteu assay } \\
\text { (mg GAE per g extract) }\end{array}$ & $\begin{array}{l}\text { Ferricyanide/Prussian } \\
\text { blue assay } \\
\left(\mathrm{EC}_{50} ; \mathrm{mg} \mathrm{mL}^{-1}\right)\end{array}$ & $\begin{array}{l}\text { DPPH radical-scavenging } \\
\text { activity assay } \\
\left(\mathrm{EC}_{50} ; \mathrm{mg} \mathrm{mL}^{-1}\right)\end{array}$ & $\begin{array}{l}\beta \text {-Carotene/linoleate } \\
\text { assay } \\
\left(\mathrm{EC}_{50} ; \mathrm{mg} \mathrm{mL}^{-1}\right)\end{array}$ & $\begin{array}{l}\text { TBARS assay } \\
\left(\mathrm{EC}_{50} ; \mathrm{mg} \mathrm{mL}^{-1}\right)\end{array}$ \\
\hline \multicolumn{6}{|l|}{ МeOH } \\
\hline Agaricus bisporus & $35.35 \pm 0.24^{\mathrm{c}}$ & $1.37 \pm 0.02^{\mathrm{b}}$ & $3.72 \pm 0.06^{\mathrm{b}}$ & $3.18 \pm 0.21^{\mathrm{c}}$ & $0.59 \pm 0.06^{\mathrm{b}}$ \\
\hline Agaricus bitorquis & $127.19 \pm 1.24^{\mathrm{a}}$ & $0.74 \pm 0.02^{\mathrm{c}}$ & $3.44 \pm 0.10^{\mathrm{c}}$ & $3.36 \pm 0.13^{\mathrm{b}}$ & $1.46 \pm 0.23^{\mathrm{a}}$ \\
\hline Agaricus campestris & $48.19 \pm 0.16^{\mathrm{b}}$ & $0.72 \pm 0.01^{\mathrm{c}}$ & $1.18 \pm 0.05^{\mathrm{d}}$ & $0.28 \pm 0.03^{\mathrm{d}}$ & $0.04 \pm 0.01^{\mathrm{c}}$ \\
\hline Agaricus macrosporus & $24.27 \pm 0.50^{\mathrm{d}}$ & $1.75 \pm 0.04^{\mathrm{a}}$ & $6.15 \pm 0.25^{\mathrm{a}}$ & $4.17 \pm 0.13^{\mathrm{a}}$ & $1.47 \pm 0.11^{\mathrm{a}}$ \\
\hline \multicolumn{6}{|l|}{ EtOH } \\
\hline Agaricus bisporus & $11.33 \pm 0.29^{c}$ & $8.07 \pm 0.19^{b}$ & $20.12 \pm 0.55^{\mathrm{b}}$ & $16.99 \pm 0.40^{\mathrm{b}}$ & $13.76 \pm 0.02^{\mathrm{a}}$ \\
\hline Agaricus bitorquis & $139.25 \pm 0.19^{\mathrm{a}}$ & $1.30 \pm 0.01^{\mathrm{c}}$ & $2.41 \pm 0.09^{c}$ & $1.29 \pm 0.20^{\mathrm{c}}$ & $2.50 \pm 0.08^{\mathrm{c}}$ \\
\hline Agaricus campestris & $56.79 \pm 1.58^{\mathrm{b}}$ & $0.88 \pm 0.02^{\mathrm{d}}$ & $0.64 \pm 0.02^{\mathrm{d}}$ & $0.48 \pm 0.02^{\mathrm{d}}$ & $0.82 \pm 0.62^{\mathrm{d}}$ \\
\hline Agaricus macrosporus & $11.78 \pm 0.12^{\mathrm{c}}$ & $9.86 \pm 0.15^{\mathrm{a}}$ & $36.05 \pm 0.89^{\mathrm{a}}$ & $17.97 \pm 1.48^{\mathrm{a}}$ & $4.71 \pm 0.47^{\mathrm{b}}$ \\
\hline
\end{tabular}

were the most abundant macronutrients present in the studied mushrooms (58-72 g per $100 \mathrm{~g}$ dw; Table 1), A. bisporus being the most rich species in these macronutrients. Ash (10-15 g per $100 \mathrm{~g} \mathrm{dw})$ and fat (2-3 g per $100 \mathrm{~g}$ dw) contents were low and their energy contribution (344-370 kcal per $100 \mathrm{~g} \mathrm{dw}$ ) was mainly due to carbohydrates and proteins (11-25 g per $100 \mathrm{~g}$ 
$\mathrm{dw}$ ). The main sugars were mannitol (5-11 g per $100 \mathrm{~g} \mathrm{dw})$, trehalose (0.6-2 g per $100 \mathrm{~g} \mathrm{dw})$ and fructose (0.3-3 g per $100 \mathrm{~g}$ $\mathrm{dw}$ ), while sucrose was detected only in A. bitorquis (1.5 g per $100 \mathrm{~g} \mathrm{dw}$; Table 1). Regarding organic acids, the main molecules found in the studied species were malic (3-4 g per $100 \mathrm{~g}$ $\mathrm{dw}$ ) and oxalic (0.3-4 g per $100 \mathrm{~g} \mathrm{dw}$ ) acids; fumaric acid was detected in lower amounts (0.2-0.6 g per $100 \mathrm{~g} \mathrm{dw}$ ), while citric acid was observed only in A. campestris $(2.4 \mathrm{~g}$ per $100 \mathrm{~g}$ $\mathrm{dw}$ ) and in A. macrosporus (0.4 g per $100 \mathrm{~g} \mathrm{dw}$ ), and malic acid in A. macrosporus (2.6 g per $100 \mathrm{~g} \mathrm{dw}$ ) (Table 1). The phenolic acids found in the present study were gallic, protocatechuic, $p$-hydroxybenzoic and p-coumaric acids, as also the related compound cinnamic acid (Table 1). Gallic acid was only found in A. bisporus (0.3 mg per $100 \mathrm{~g} \mathrm{dw}$ ), protocatechuic (1.1 mg per $100 \mathrm{~g} \mathrm{dw}$ ) and p-hydroxybenzoic (4.1 mg per $100 \mathrm{~g} \mathrm{dw}$ ) acids in A. macrosporus, and p-coumaric acid in A. bisporus (0.1 $\mathrm{mg}$ per $100 \mathrm{~g} \mathrm{dw}$ ) and A. macrosporus (0.7 mg per $100 \mathrm{~g}$ $\mathrm{dw})$; cinnamic acid was quantified in all the species (0.1-1.8 mg per $100 \mathrm{~g} \mathrm{dw}$ ) (Table 1).

Concerning the fatty acid composition of the studied species (Table 2), polyunsaturated fatty acids (PUFA, 62-76\% of total fatty acids (FA)) predominated over saturated fatty acids (SFA, 21-23\% of total FA) and monounsaturated fatty acids (MUFA, 3-15\% of total FA). A. bisporus and A. bitorquis presented the highest content in SFA, the first species also in MUFA, while A. macrosporus gave the highest percentage of PUFA (Table 2). Thus, all the species seem to be excellent options as food. The fatty acids found in higher amounts were palmitic acid (C16:0, SFA); oleic acid (C18:1n9, MUFA), and linoleic acid (C18:2n6, PUFA). Similar profiles were detected in cultivated species from Portugal. ${ }^{11}$ Regarding tocopherols, $\alpha$-, $\beta$-, $\gamma$ - and $\delta$ - isoforms were quantified (Table 2). $\beta$-Tocopherol was only found in A. bisporus (25 $\mu \mathrm{g}$ per $100 \mathrm{~g} \mathrm{dw}$ ), while $\delta$-tocopherol was detected in A. bitorquis (18 $\mu \mathrm{g}$ per $100 \mathrm{~g} \mathrm{dw})$. Total tocopherols were presented in higher concentration $(116 \mu \mathrm{g}$ per $100 \mathrm{~g} \mathrm{dw})$ in A. campestris due to the contribution of $\gamma$-tocopherol $(110 \mu \mathrm{g}$ per $100 \mathrm{~g} \mathrm{dw})$ (Table 2$)$.

\subsection{Antioxidant and antimicrobial activities of Agaricus spp. extracts}

Antioxidant activity of the investigated Agaricus species is presented in Table 3. Both methanolic and ethanolic extracts of the studied species have shown antioxidant potential, but the first one was better in most of the cases (Table 3). Methanolic and ethanolic extracts of $A$. bitorquis presented the highest total phenolic content (127 and $130 \mathrm{mg}$ GAE per g extract, respectively). Among the methanolic extracts, A. campestris revealed the highest reducing power $\left(\mathrm{EC}_{50}=0.7 \mathrm{mg} \mathrm{mL}{ }^{-1}\right)$, $\mathrm{DPPH}$ scavenging activity $\left(\mathrm{EC}_{50}=1.2 \mathrm{mg} \mathrm{mL}{ }^{-1}\right), \beta$-carotene bleaching inhibition $\left(\mathrm{EC}_{50}=0.3 \mathrm{mg} \mathrm{mL} \mathrm{mL}^{-1}\right)$ and TBARS formation decrease $\left(\mathrm{EC}_{50}=0.04 \mathrm{mg} \mathrm{mL}{ }^{-1}\right)$. The same tendency was observed for ethanolic extracts $\left(\mathrm{EC}_{50}=0.9,0.6,0.5\right.$ and $0.8 \mathrm{mg} \mathrm{mL}{ }^{-1}$, respectively; Table 3 ). This species (A. campestris) was also the one that showed the highest phenolic acid concentration (Table 2). To date there are various antioxidant activity assays, each one having their specific target within the matrix and all of them with advantages and disadvantages. There is not one method that can provide unequivocal results and the best solution is to use various methods instead of a one-dimension approach. Some of these procedures use free radicals, some are specific for lipid peroxidation and tend to need animal or plant cells, some have a broader scope, some require minimum preparation and knowledge, few reagents and are quick to produce outputs. Thus, it is very important to use different antioxidant assays in order to get a better overview of the results and applicability of natural matrices such are mushrooms.

The results of antibacterial and antifungal activities of methanolic and ethanolic extracts of the tested Agaricus species are presented in Table 4 . Ethanolic extracts of all the tested species exhibited higher antibacterial activity than methanolic ones, with exception towards L. monocytogenes. The best antibacterial effect was achieved by A. macrosporus extracts against all bacteria, except $L$. monocytogenes. A. bitorquis extracts showed the best effect against this bacterium. Extracts of $A$. bisporus possessed the lowest antibacterial activity among all the others. The antibacterial activity displayed by the extracts was lower than that demonstrated by the antibiotics.

Ethanolic extracts of all the tested species showed once more the highest antifungal activity, with few exceptions; A. bisporus ethanolic extract exhibited a lower effect than methanolic extracts towards A. ochraceus and T. viride, and A. macrosporus ethanolic extract possessed lower effect than methanolic extract against P. funiculosum and P. ochrochloron. The best antifungal activity was obtained for A. macrosporus extracts against all the tested microfungi. These extracts also showed higher or similar inhibitory activity than ketoconazole, and an even higher fungicidal effect against $P$. funiculosum. Extracts of $A$. campestris exhibited the worst antifungal potential among all the tested strains.

\subsection{Antiquorum sensing activity of Agaricus spp. extracts}

The effect of Agaricus spp. ethanolic extracts on the biofilm formation of $P$. aeruginosa was tested with $0.5,0.25$ and 0.125 of the determined MIC. Table 5 shows that all the tested extracts, at 0.5 MIC, reduced biofilm formation more than streptomycin and ampicillin. The extracts reduced biofilm formation in the range of $53-87 \%$, which means that the biofilm was formed in the presence of extracts in the range of $13-47 \%$. The best results were observed for the A. macrosporus extract, while A. campestris showed the lowest reduction of biofilm formation. Streptomycin and ampicillin reduced biofilm by $51 \%$ and $31 \%$, respectively. Extracts tested at 0.25 MIC exhibited slightly higher reduction of biofilm production than positive controls, while at 0.125 MIC they possessed lower activity.

The quorum-sensing inhibition zones were determined by the disc diffusion method. It can be seen that the extracts of A. bisporus $(8.0-15.0 \mathrm{~mm})$ and A. bitorquis $(7.0-8.7 \mathrm{~mm})$ showed antiquorum sensing (AQ) activity at all concentrations. Ampicillin possessed AQ activity at higher concentration (7.6 $\mathrm{mm})$, while streptomycin showed the best AQ activity presenting the zones in the range of 15.5-22.6 $\mathrm{mm}$. 
Table 4 Antimicrobial activity of the methanolic $(\mathrm{MeOH})$ and ethanolic $(\mathrm{EtOH})$ extracts of the studied Agaricus spp. $(\mathrm{mean} \pm \mathrm{SD})^{\mathrm{a}}$

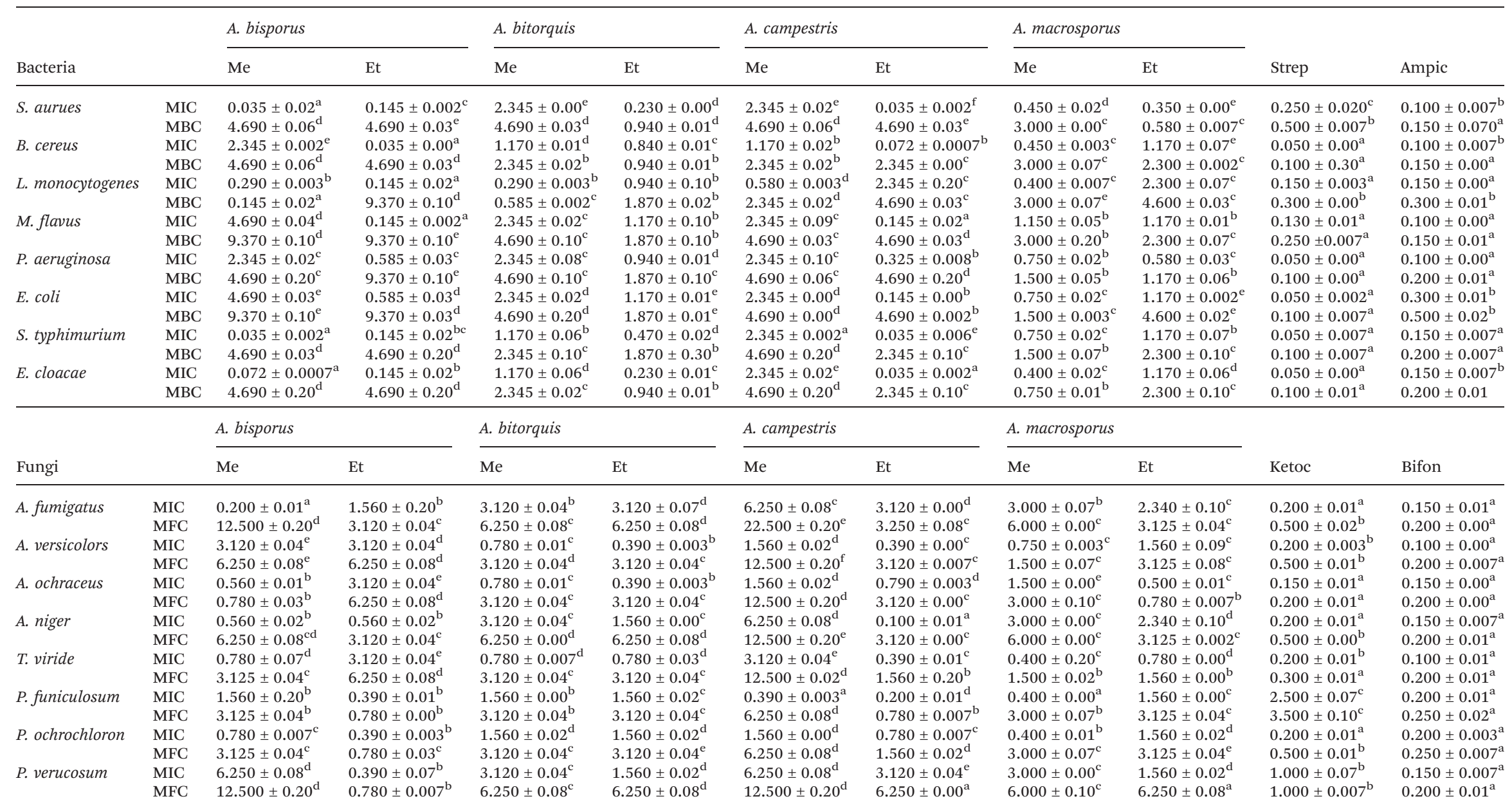

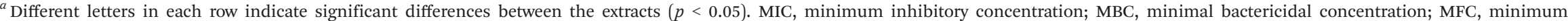
fungicidal concentration. 
Table 5 Effects of Agaricus spp. ethanolic extracts on biofilm formation of $P$. aeruginosa (PAO1) and disc-diffusion method for detection of antiquorum (AQ) concentrations

\begin{tabular}{|c|c|c|c|c|c|c|}
\hline Agents & \multicolumn{3}{|c|}{ Biofilm formation* (\%) } & \multicolumn{3}{|l|}{ AQ (mm) } \\
\hline Agaricus bitorquis & $26.33 \pm 0.46^{\mathrm{c}}$ & $64.70 \pm 0.65^{\mathrm{a}}$ & $107.54 \pm 1.70^{\mathrm{a}}$ & $8.30 \pm 0.58^{\mathrm{a}}$ & $7.00 \pm 1.0^{\mathrm{b}}$ & $8.70 \pm 1.15^{\mathrm{b}}$ \\
\hline Agaricus campestris & $47.45 \pm 0.06^{\mathrm{a}}$ & $50.11 \pm 0.03^{c}$ & $98.78 \pm 1.30^{\mathrm{c}}$ & - & - & - \\
\hline Agaricus macrosporus & $13.06 \pm 0.03^{\mathrm{d}}$ & $50.11 \pm 0.30^{\mathrm{c}}$ & $89.37 \pm 0.46^{\mathrm{d}}$ & - & - & - \\
\hline Ampicillin & $69.16 \pm 0.65^{\mathrm{a}}$ & $56.46 \pm 0.46^{\mathrm{c}}$ & $92.16 \pm 0.37^{\mathrm{c}}$ & - & - & $7.60 \pm 0.6^{\mathrm{c}}$ \\
\hline
\end{tabular}

Values are expressed as means \pm SD. Different letters in each row indicate significant differences between the extracts $(p<0.05)$. ${ }^{*}$ Biofilm formation values were calculated as: (mean $A_{620}$ treated well)/(mean $A_{620}$ control well) $\times 100$. - No effect of AQ.

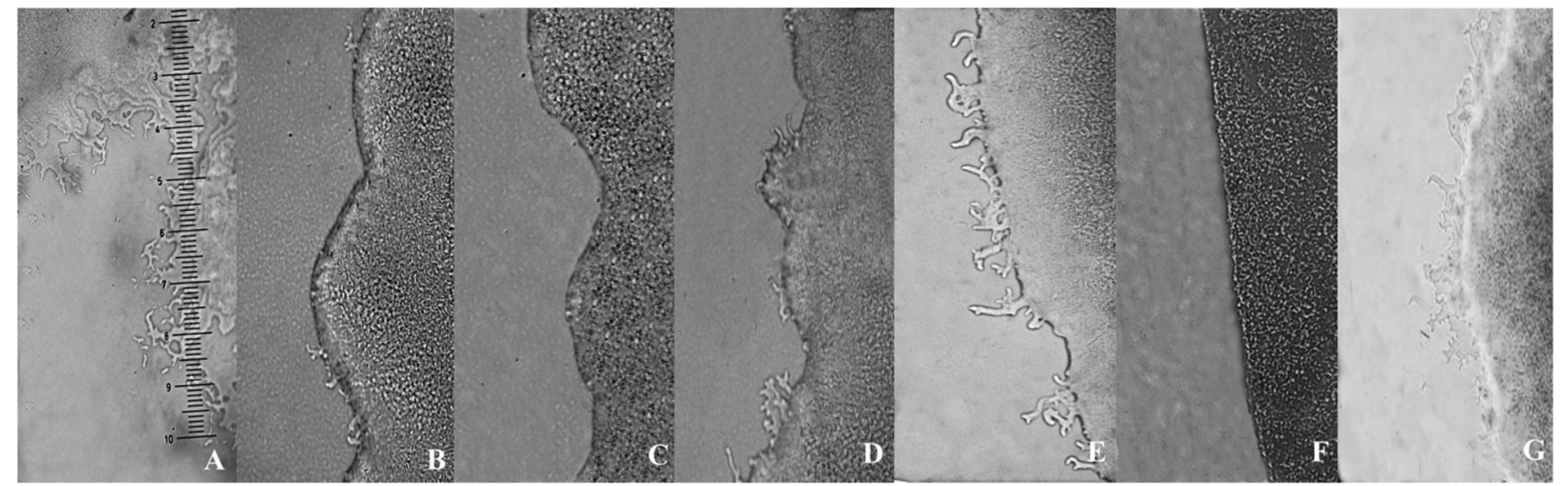

Fig. 1 Light microscopy of colony edges of $P$. aeruginosa in twitching motility plates, grown in the presence or absence of Agaricus spp. ethanolic extracts. A - A. bisporus, B - A. bitorquis, C - A. campestris, D - A. macrosporus, E - control P.a. 10 ${ }^{9}, \mathrm{~F}-$ Streptomycin, $\mathrm{G}-\mathrm{Ampicillin}$.

Promising anti-quorum sensing compounds have been demonstrated to disrupt bacterial biofilms and make the bacteria more susceptible to antibiotics, and these compounds also provide the ability to reduce bacterial virulence factors as well as promote clearance of bacteria in infectious animal models. Many mechanisms of action have been proposed to interfere with the quorum sensing system such as inhibition of biosynthesis of autoinducer molecules, inactivation or degradation of the autoinducer, interference with the signal receptor, and inhibition of the genetic regulation system. ${ }^{23}$

In addition to QS, the initiation of biofilm formation by $P$. aeruginosa depends on two cell-associated structures: the flagellum and type IV pili. ${ }^{21}$ The flagellum is responsible for swimming motility, while the type IV pili is responsible for twitching motility. Both types of motilities are important in the initial stages of biofilm formation by $P$. aeruginosa. ${ }^{21}$ Therefore, we tried to determine whether our extract influences either one or both motilities. On swimming plates, the motile strain PAO1 was used as the $100 \%$ standard (control) for motility while the Petri dishes with the same strain plus Agaricus spp. extracts were compared with control. The extracts reduced the twitching motility of $P$. aeruginosa. The normal colonies of P. aeruginosa, i.e. in the absence of the extract, were flat with a rough appearance displaying irregular colony edges and a hazy zone surrounding the colony (Fig. 1E). The cells were in a very thin layer. After 2 days of incubation at ambient temperature, colony expansion occurred very rapidly due to twitching motility, and the control $P$. aeruginosa isolates produced swimming zones up to $100 \%$ and they were $14 \mathrm{~mm}$ in diameter. Bacteria that were grown with the Agaricus spp. extract solution were incapable of producing such a twitching zone and had almost round, smooth, regular colony edges, the flagella were reduced both in size and in numbers, and the colony diameter of the swimming zones was also reduced (18-32 mm) (Fig. 1A-D). All the Agaricus extracts reduced flagella with the exception of A. bisporus extract. The flagella reduction was achieved in the order A. campestris $>$ A. bitorquis $>$ A. macrosporus (Fig. 1C, 1B, $1 \mathrm{D}$, respectively). Streptomycin completely reduced the flagella (Fig. 1F), while ampicillin did not affect the formation of flagella at all (Fig. 1G). The best twitching effect was achieved for A. bitorquis extract $(18 \mathrm{~mm})<$ A. bisporus $(26 \mathrm{~mm})<$ A. campestris $(29 \mathrm{~mm})<A$. macrosporus $(32 \mathrm{~mm})$.

In summary, our study indicated that Agaricus extracts possessed antimicrobial, antibiofilm and anti-quorum sensing activity. Inhibition of bacterial quorum sensing offers a new strategy for the treatment of bacterial infections. The anti- 
quorum sensing properties of these mushroom species may play an important role in antibacterial activity and offer an additional strategy for fighting bacterial infection.

In the present study a complete chemical characterization of the edible species A. bisporus, A. bitorquis, A. campestris and A. macrosporus was performed.

Data obtained for carbohydrates are in agreement with the values stated by different authors who reported mushrooms as good sources of carbohydrates and proteins as well as poor in fat and low caloric foods. ${ }^{1,11}$ Mannitol and trehalose are very common sugars found in mushrooms as reported by several authors. ${ }^{1,11,24}$ Due to the several applications of mannitol in food, pharmaceutical, medical, and chemical industries, the studied species are, also for this, considered valuable healthy foods; furthermore almost all species did not present other less healthy sugars like fructose or sucrose. ${ }^{25}$ The phenolic profile of each one of the studied species was different. Nevertheless, the phenolic acid profile of the A. bisporus sample studied herein was similar to the one described for $A$ bisporus samples from Finland ${ }^{26}$ and Portugal. ${ }^{15}$ Other Agaricus species presented different profiles: $p$-coumaric and cinnamic acids in $A$. brasiliensis ${ }^{27} p$-hydroxybenzoic and $p$-coumaric acids, and two related compounds, $\gamma$-L-glutaminyl-4-hydroxybenzene (GHB) and cinnamic acid, in $A$. bohusii. ${ }^{28}$ All species seem to be excellent options with regard to their fatty acid content and composition; A. macrosporus may be a better choice since it has a lower percentage of SFA. Although organic acids are a product of the primary metabolism, some of these may also have bioactive properties such as malic acid that has been employed for the preparation of food additives and for the synthesis of various fine chemicals. ${ }^{29,30}$ Different isoforms of tocopherols ( $\alpha$-, $\beta$-, $\gamma$ - and $\delta$-) were also found in the studied mushrooms, as also in other cultivated species. ${ }^{31,32}$

Among the studied mushrooms, A. bisporus is the best investigated especially regarding fatty acids and antioxidant activity. $^{33-36}$ The other species are not so well investigated; only a recent study on $A$. bitorquis chemical and nutritional composition is available ${ }^{36}$

A. campestris was the species with the highest antioxidant activity, probably due to its highest content in phenolic acids and tocopherols, known as powerful antioxidant molecules. ${ }^{3}$

Regarding the antibacterial and antifungal potential, the ethanolic extracts were more effective than the methanolic ones. Antimicrobial activity of three Agaricus species was also recently published by Ozturk et al. ${ }^{37}$ who described effects of methanolic extracts against six species of Gram-positive bacteria, seven species of Gram-negative bacteria and two species of yeasts. The methanolic extract of $A$. campestris from India showed antimicrobial activity against seven bacterial species. ${ }^{38}$

\section{Conclusion}

Overall, the studied Agaricus species were found to be good sources of nutritional and bioactive compounds, and methanolic/ethanolic extracts showed antioxidant, antimicrobial and antiquorum properties. Thus, this study brings additional chemical and biochemical knowledge for these edible mushroom species, which can be applied in the food industry as natural preservatives.

\section{Conflict of interest}

The authors have no conflicts of interest.

\section{Acknowledgements}

The authors are grateful to Fundação para a Ciência e a Tecnologia (FCT, Portugal), COMPETE/QREN/EU for financial support to this work (CIMO strategic project PEst-OE/AGR/ UI0690/2011 and L. Barros researcher contract under "Programa Compromisso com Ciência-2008”), and to the Serbian Ministry of Education, Science and Technological Development for financial support (grant number 173032).

\section{References}

1 P. Kalač, J. Sci. Food Agric., 2013, 93, 209-218.

2 J. J. Cheng, C. Y. Lin, H. S. Lur, H. P. Chen and M. K. Lu, Process Biochem., 2008, 43, 829-834.

3 I. C. F. R. Ferreira, L. Barros and R. M. V. Abreu, Curr. Med. Chem., 2009, 16, 1543-1560.

4 I. C. F. R. Ferreira, J. A. Vaz, M. H. Vasconcelos and A. Martins, Anti-Cancer Agents Med. Chem., 2010, 10, 424436.

5 S. C. Jeong, Y. T. Jeong, B. K. Yang, R. Islam, S. R. Koyyalamudi, G. Pang, K. Y. Cho and C. H. Song, Nutr. Res., 2010, 30, 49-56.

6 C. Moro, I. Palacios, M. Lozano, M. D’Arrigo, E. Guillamón, A. Villares, J. A. Martínez and A. García-Lafuente, Food Chem., 2012, 130, 350-355.

7 M. Kuo, The genus Agaricus. Retrieved from the MushroomExpert.Com http://www.mushroomexpert.com/ agaricus.html).

8 S. Tachakittirungrod, S. Okonogi and S. Chowwanapoonpohn, Food Chem., 2007, 103, 381-388.

9 A. M. Assaf, R. N. Haddadin, N. A. Aldouri, R. Alabbassi, S. Mashallah, M. Mohammad and Y. Bustanji, J. Ethnopharmacol., 2013, 145, 728-736.

10 G. W. Latimer Jr., AOAC Official methods of analysis, Association of Official Analytical Chemists, Arlington VA, USA, 16 th edn, 1995.

11 F. S. Reis, L. Barros, A. Martins and I. C. F. R. Ferreira, Food Chem. Toxicol., 2012a, 50, 191-197.

12 L. Barros, C. Pereira and I. C. F. R. Ferreira, Food Anal. Methods, 2013, 6, 309-316.

13 L. Barros, M. Dueñas, I. C. F. R. Ferreira, P. Baptista and C. Santos-Buelga, Food Chem. Toxicol., 2009, 47, 1076-1079.

14 S. A. Heleno, L. Barros, M. J. Sousa, A. Martins and I. C. F. R. Ferreira, Food Chem., 2010, 119, 1443-1450. 
15 F. S. Reis, A. Martins, L. Barros and I. C. F. R. Ferreira, Food Chem. Toxicol., 2012b, 50, 1201-1207.

16 CLSI. Clinical and Laboratory Standards Institute., Methods for dilution antimicrobial susceptibility tests for bacteria that grow aerobically, Approved standard, CLSI publication M07A8. Clinical and Laboratory Standards Institute, Wayne, PA, 8th edn, 2009.

17 T. Tsukatani, H. Suenaga, M. Shiga, K. Noguchi, M. Ishiyama, T. Ezoe and K. Matsumoto, J. Microbiol. Methods, 2012, 90, 160-166.

18 A. Espinel-Ingroff, J. Clin. Microbiol., 2001, 39, 1360-1367.

19 E. Drenkard and F. M. Ausubel, Nature, 2002, 416, 740-743.

20 V. O’May and N. Tufenkji, Appl. Environ. Microbiol., 2011, 77, 3061-3067.

21 G. A. O’Toole and R. Kolter, Mol. Microbiol., 1998a, 30, 295304.

22 S. M. Sandy and T. Foong-Yee, Malays. J. Microbiol., 2012, 8, 11-20.

23 T. B. Rasmussen and M. Givskov, Microbiology, 2006, 152, 895-904.

24 C. Grangeia, S. A. Heleno, L. Barros, A. Martins and I. C. F. R. Ferreira, Food Res. Int., 2011, 44, 1029-1035.

25 W. Soetaert, Production of mannitol with Leuconostoc mesenteroides, Mededelingen van de Faculteit Landbouwwetenschappen, Rijksuniversiteit Gent, 1990, 55, 1549-1552.

26 P. Mattila, K. Könkö, M. Eurola, J.-M. Pihlava, J. Astola, L. Vahteristo, V. Hietaniemi, J. Kumpulainen, M. Valtonen and V. Piironen, J. Agric. Food Chem., 2001, 49, 2343-2348.
27 D. Stojković, F. S. Reis, J. Glamočlija, A. Ćirić, L. Barros, L. J. L. D. van Griensven, I. C. F. R. Ferreira and M. Soković, Food Funct., 2014, 5, 1602-1612.

28 F. S. Reis, D. Stojković, M. Soković, J. Glamočlija, A. Ćirić, L. Barros and I. C. F. R. Ferreira, Food Res. Int., 2012c, 48, 620-626.

29 E. Battat, Y. Peleg, A. Bercovitz, J. S. Rokem and I. Goldberg, Biotechnol. Bioeng., 1991, 37, 1108-1116.

30 G. T. Tsao, N. J. Cao, J. Du and C. S. Gong, Adv. Biochem. Eng. Biotechnol., 1999, 65, 243-280.

31 T. Jayakumar, P. A. Thomas and P. Geraldine, Innov. Food Sci. Emerg. Technol., 2009, 10, 228-234.

32 S. Y. Tsai, S. J. Huang, S. H. Lo, T. P. Wu, P. Y. Lian and J. L. Mau, Food Chem., 2009, 113, 578-584.

33 M. F. Leon-Guzman, I. Silva and M. G. López, J. Agric. Food Chem., 1997, 45, 4329-4332.

34 L. Barros, P. Baptista, D. M. Correia, S. Casal, B. Oliveira and I. C. F. R. Ferreira, Food Chem., 2007, 105, 140-145.

35 N. Yilmaz, M. Solmaz, I. Turkekul and M. Elmastas, Food Chem., 2006, 99, 168-174.

36 S. Saiqa, N. B. Haq, A. H. Muhammad, M. A. Ali and Ata-ur-Rehman, Iran. J. Chem. Chem. Eng., 2008, 27, 151154.

37 M. Ozturk, M. E. Duru, S. Kivrak, N. Mercan-Dogan, A. Turkoglu and M. A. Ozler, Food Chem. Toxicol., 2011, 49, 1353-1360.

38 S. Giri, G. Biswas, P. Pradhan, S. C. Mandal, K. Achary and K. Acharya, Int. J. PharmTech Res., 2012, 4, 154-1560. 